\title{
Penggunaan Media Gambar Seri sebagai Upaya Meningkatkan Kemampuan Menulis Karangan Cerita pada Pembelajaran Bahasa Indonesia
}

\author{
Diterima: \\ 6 Januari 2021 \\ Revisi: \\ 29 Januari 2021 \\ Terbit: \\ 1 Februari 2021
}

\author{
Ratna Kurnia Aziezah \\ SDN Miru Lamongan \\ Lamongan, Indonesia \\ E-mail: ziezie.antar@gmail.com
}

\begin{abstract}
Abstrak - Pembelajaran Bahasa Indonesia mencakup empat aspek yaitu mendengarkan, berbicara, membaca dan menulis. Keempat kemampuan tersebut bersifat integral atau saling berhubungan. Dari keempat aspek tersebut, keterampilan menulis diakui sebagai keterampilan yang paling sulit. Kenyataan membuktikan bahwa keterampilan menulis tidak banyak dikuasai oleh masyarakat kita pada umumnya atau para siswa pada khususnya. Maka salah satu upaya yang dapat dilakukan guru dalam mengajar bahasa Indonesia adalah meningkatkan kemampuan menulis sebuah karangan dengan memanfaatkan sebuah media. Salah satunya adalah media gambar, karena media gambar dapat merangsang minat siswa sehingga daya imajinasinya timbul dan dituangkan dalam bentuk karya tulis yaitu sebuah karangan. Melalui pemanfaatan media gambar akan dianalisis untuk mengetahui apakah media gambar dapat meningkatkan kemampuan menulis sebuah karangan cerita. Penelitian ini menggunakan metode penelitian diskriptif kuantitatif. Dengan subyek penelitian siswa kelas V SDN Miru Kecamatan Sekaran Kabupaten Lamongan dengan jumlah siswa 16 anak. Teknik pengumpulan data melalui metode observasi dan metode experiment. Observasi dilakukan untuk mengamati aktifitas siswa dan guru dalam kegiatan belajar mengajar dengan menggunaan media gambar. Experimen yaitu melakukan percobaan dengan mengalami dan membuktikan sendiri sesuatu yang dipelajari. Siswa diminta untuk membuat karangan sebanyak-banyaknya. Hasil penelitian menunjukkan ada peningkatan dalam menulis sebuah karangan dari siklus I dan siklus II. Pada kegiatan siklus II ketuntasan minimal meningkat daripada pembelajaran siklus I. Pada siklus I siswa yang tuntas belajar 5 anak dengan prosentase ketuntasan $31,25 \%$. Sedangkan pada siklus II siswa yang tuntas belajar 14 anak dengan prosentase ketuntasan 87,5\%. Ini berarti bahwa pemanfaatan media gambar dalam proses pembelajaran Bahasa Indonesia dapat meningkatkan kemampuan siswa dalam menulis sebuah karangan.
\end{abstract}

Kata Kunci - media, gambar seri, menulis karangan

Abstract - In learning Indonesian includes four aspects, namely listening, speaking, reading and writing. The four abilities are integral or interconnected. Of the four aspects, writing skill is recognized as the most difficult skill. The fact proves that writing skills are not widely mastered by our society in general or students in particular. So one of the efforts that teachers can do in teaching Indonesian is to improve the ability to write an essay by utilizing a media. One of them is image media, because image media can stimulate students' interest so that their imagination power arises and is poured in the form of written work, namely an essay. Through the use of image media, it will be analyzed to find out whether image media can improve the ability to write an essay. The research method uses descriptive quantitative research methods. The research subjects were fifth graders at SDN Miru, Sekaran District, Lamongan Regency with 16 students. Data collection techniques through observation and experimental methods. Observations were made to observe the activities of students and teachers in teaching and learning activities using image media. Experiment is to do an experiment by experiencing and proving for yourself something that is learned. Students are asked to write as many essays as possible. The results showed that there was an increase in writing an essay from cycle I and cycle II. In the second cycle, the minimum completeness increased than in the first cycle. In the first cycle, 5 students completed their study with a mastery percentage of $31.25 \%$. Meanwhile, in the second cycle, 14 students completed their study with a 
mastery percentage of $87.5 \%$. This means that the use of image media in the Indonesian language learning process can improve students' ability to write an essay.

Keywords-media, drawing series, writing essays

\section{PENDAHULUAN}

Bahasa merupakan dasar bagi pengetahuan siswa, sehingga pengajaran bahasa adalah inti dan dasar bagi mata pelajaran yang lain. Terutama bagi siswa Sekolah Dasar (SD). Kemampuan berbahasa seseorang sangat diperlukan dan harus berkembang bersama-sama dengan perkembangan bahasa mengikuti jaman (Safaria, Diponegoro, and Bashori 2017).

Dalam pembelajaran bahasa Indonesia mencakup empat aspek yaitu mendengarkan, berbicara, membaca dan menulis. Sedangkan kemampuan berbahasa memiliki empat komponen yaitu, keterampilan menyimak, keterampilan berbicara, keterampilan membaca dan keterampilan menulis. Keterampilan-keterampilan tersebut bersifat integral, saling berhubungan. Berbicara dan menyimak merupakan keterampilan berbahasa yang bersifat langsung. Berbicara dipelajari melalui keterampilan menyimak. Peningkatan keterampilan menyimak akan meningkatkan keterampilan berbicara. Keterampilan berbicara diperoleh sebelum pemerolehan keterampilan membaca. Pembelajaran keterampilan membaca pada tingkat lanjut akan membantu keterampilan berbicara, keterampilan berbicara diperoleh sebelum pembelajaran keterampilan menulis. Kebiasaan membaca tidak mungkin terlaksana tanpa kebiasaan menulis atau mengarang, kebiasaan menulis tidak akan bermakna tanpa diikuti oleh kebiasaan membaca. Keterampilan menulis diakui sebagai keterampilan yang paling sulit (Purwanto 2010).

Berdasarkan penilaian awal di SDN Miru khususnya kelas V, tingkat kemampuan siswa dalam keterampilan menulis ternyata masih rendah. Hal ini disebabkan karena kurangnya kebiasaan siswa dalam menulis dan tidak adanya media dalam pembelajaran sehingga siswa kurang aktif dan cenderung pasif dalam pembelajaran. Untuk mengatasi hal ini diperlukan keterampilan dalam meningkatkan ketelitian, keuletan dan strategi untuk menumbuhkan minat siswa dalam keterampilan menulis. Salah satu strategi yang digunakan untuk mencapai tujuan yang maksimal yaitu menggunakan media pembelajaran.

Hamalik (1986) mengemukakan bahwa pemakaian media pembelajaran dalam proses belajar mengajar dapat membangkitkan keinginan dan minat yang baru, membangkitkan motivasi dan rangsangan kegiatan belajar, dan membawa pengaruh-pengaruh psikologis terhadap siswa.

Salah satu media yang dapat digunakan dalam pengajaran keterampilan menulis adalah media gambar seri. Media gambar seri selain murah dan mudah didapat juga dapat menghasilkan obyek secara konkrit sehingga dapat merangsang dan menimbulkan daya kreasi PTK: Jurnal Tindakan Kelas | Hal:94-100 
PTK, Vol.2 No.2 2022

ISSN: 2747-1977 (Print) / 2747-1969 (Online)

DOI: https://doi.org/10.53624/ptk.v2i2.56

siswa, misalnya mengarang suatu ceritera atau menulis sebuah puisi. Dalam penggunaan media harus disesuaikan dengan materi yang diajarkan. Selain itu juga harus memperhatikan jumlah siswa.

Dengan demikian dapat disimpulkan bahwa gambar dapat merangsang imajinasi dan inspirasi siswa dalam menulis yang nantinya diharapkan melalui gambar siswa akan terampil menggunakan ide serta gagasan baru yang akan digabungkan dengan gagasan lama yang berbentuk pikiran dan dituangkan dalam bentuk tulisan yaitu sebuah karangan. Itu berarti kegiatan belajar anak didik dengan bantuan media akan menghasilkan proses dan hasil belajar yang lebih baik daripada tanpa bantuan media.

\section{METODE}

\section{A. Pendekatan penelitian}

Pendekatan yang digunakan adalah penelitian kualitatif dengan desain Penelitian Tindakan Kelas (PTK), dengan tahapan 1) perencanaan, 2) pelaksanaan, 3) pengamatan, 4) refleksi. Penelitian ini direncanakan berlangsung selama 2 siklus, tiap siklus 2 pertemuan dengan materi menganalisis gambar seri, secara keseluruhan, tindakan kelas pada materi siklus air ini terdiri dari empat pertemuan, dua pertemuan pada siklus pertama, dan dua pertemuan pada siklus kedua. Menurut materi pembelajaran pada empat pertemuan tersebut antara lain: (1) pengertian media gambar dan contoh masing-masing macamnya, (2) jenis-jenis gambar seri, (3) factor yang memengaruhi dan fungsi dari gambar seri, (4) manfaat masing-masing bagi keidupan manusia dan peran manusia dalam menganalisis gambar. Adapun alur siklus PTK yang digambarkan dibawah ini.

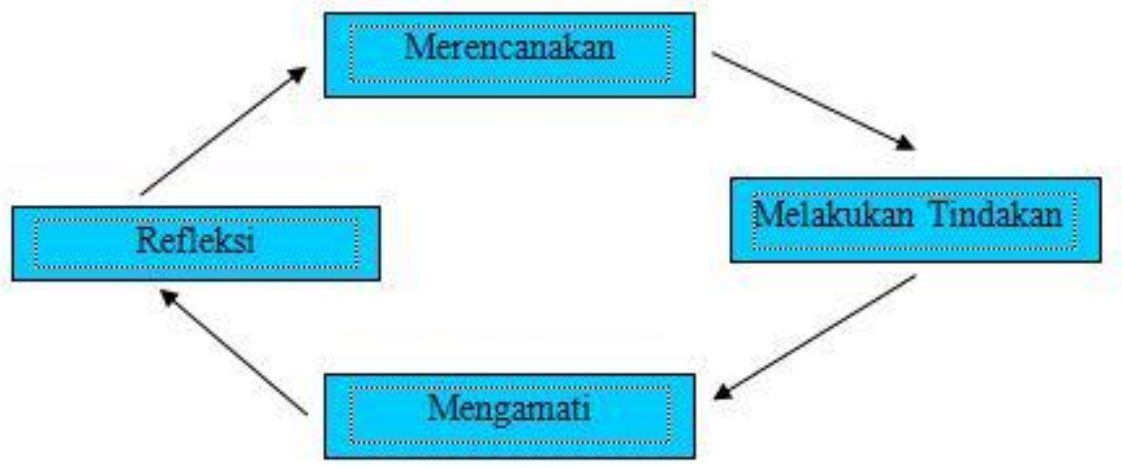

Gambar 1. Siklus Penelitian

Siklus I, Siklus ini terdiri dari empat tahap yaitu perencanaan, pelaksanaan, pengamatan dan refleksi. Berikut penjelasan masing-masing tahapannya. Perencanaan, langkah-langkah ini 
terdiri dari pengembangan RPP, penyiapan media pembelajaran alat peraga/media gambar seri, LKPD, soal evaluasi, dan lembar observasi pelaksanaan pembelajaran. Pelaksanaan, pada tahap ini peneliti melaksanakan pembelajaran pada materi Menulis karangan melalui media gambar seri. Observasi, tahap ini dilakukan pada saat pembelajaran jarak jauh dilakukan oleh siswa, peneliti sebagai guru melakukan observasi jarak jauh proses pengerjaan lembar kerja oleh siswa melalui foto-foto saat siswa belajar dari rumah. Refleksi, pada tahap ini peneliti mengkaji ulang pembelajaran yang telah dilaksanakan, apa yang sudah dan belum tercapai, masalah-masalah apa saja yang muncul, dan menyiapkan berbagai alternatif pemecahan masalah agar pada siklus berikutnya lebih maksimal. Siklus II, Siklus ini memiliki tahapan yang sama dengan siklus I yaitu perencanaan, pelaksanaan, observasi dan refleksi. Apa yang belum tercapai dalam siklus I bisa diteruskan pada siklus II ini. Kegiatan pada siklus ini menyesuaikan dengan permasalahan pembelajaran pada siklus I. Setelah siklus II berakhir maka penelitian ini dihentikan.

\section{B. Subjek Penelitian}

Subjek yang diteliti pada penelitian ini adalah siswa kelas V semester genap tahun ajaran 2018/2019 di SDN Miru Kecamatan Sekaran Kabupaten Lamongan dengan jumlah siswa 15 siswa.

\section{Waktu Pelaksanaan}

Waktu pelaksanaan dilaksanakan mulai tanggal 1 September sampaai tanggal 23 September 2019 semester genap tahun pelajaran 2018/2019.

\section{Data dan Instrumen Penilaian}

Data pada penelitian ini adalah data berupa ketercapaian pembelajaran menggunakan media gambar seri menggunakan instrument lembar observasi dan data hasil belajar siswa pada materi menganalisis gambar berseri. Data ketercapaian pembelajaran merupakan data kualitatif berupa catatan-catatan guru terhadap kekuatan dan kelemahan proses pembelajaran, sedangkan data hasil belajar merupakan data kuantitatif yang akan diambil sebanyak empat kali selama dua siklus (dua kali pada masing-masing siklus). Data hasil belajar diambil dari soal evaluasi, soal ini dikembangkan menjadi lima soal pilihan ganda dan tujuh soal jawaban singkat, kriteria ketuntasan minimal (KKM) pengerjaan soal ini adalah mendapatkan skor 75\%.

\section{E. Teknik Analisis Data}

Analisis data pada penelitian ini menggunakan teknik kualitatif dan kuantitatif. Untuk data kualitatif adalah data ketercapaian pembelajaran, yaitu data kekuatan dan kelemahan pembelajaran di bahas, direfleksikan, dan di rumuskan simpulannya. Untuk data deskriptif 
PTK, Vol.2 No.2 2022

ISSN: 2747-1977 (Print) / 2747-1969 (Online)

DOI: https://doi.org/10.53624/ptk.v2i2.56

kuantitatif adalah data angka hasil belajar siswa, dibandingkan dengan KKM, dianalisis, dan dimaknai secara deskriptif.

\section{HASIL DAN PEMBAHASAN}

Pembelajaran materi menulis karangan cerita menggunakan media gambar seri berbantu gambar seri diawali dengan siswa diminta (1) memperhatikan alat peraga yang dipasang oleh guru berupa gambar seri yang tersusun acak. (2) Kemudian siswa secara bergantian maju untuk menyusun gambar seri secara runtut.(3) Siswa diminta mencari ide pokok dari setiap gambar yang telah disusun. Kemudian siswa diminta untuk menyampaikan hasil pengamatannya.

Pada saat mengamati gambar dengan teliti, dipastikan akan terjadi proses kognitif yang tinggi saat melakukan pengamatan dan penyusunan gambar seri, selain itu terlihat dokumentasi kegiatan, siswa menyampaikan ide pokok setiap gambar serinya dengan baik. Siswa merasa bermain, namun sebetulnya ada proses belajar disana.

Hal diatas, diaharapkan dapat meningkatkan memori siswa dalam menyusun kalimat karangan denga benar. Sesuai dengan beberapa pelaksanaannya, bahwa (1) mengamati gambar seri dapat menarik minat belajar siwa, (2) gambar seri dapat mengatasi keterbatasan ruang dan waktu, (3) dengan adanya media pembelajaran siswa dapat melihat, mengamati, dan melakukan percobaan serta dapat menambah wawasan.

Setelah siswa menyelesaikan media gambar seri, maka tahap berikutnya adalah siswa mengerjakan lembar kerja peserta didik (LKPD) berdasarkan media gambar seri yang berisis gambar-gambar seri tanpa teks bacaan. Melalui media yang menarik, membuat siswa lebih antusias dalam mengerjakan LKPD.

Tabel 1. Hasil Belajar Siswa pada Materi Kemampuan Menganalisis Siklus Air

\begin{tabular}{|c|c|c|c|c|c|}
\hline \multirow[t]{2}{*}{ No. } & \multirow[t]{2}{*}{ Nama (Inisial) } & \multicolumn{2}{|c|}{ Skor Evaluasi Siklus 1} & \multicolumn{2}{|c|}{ Skor Evaluasi Siklus 2} \\
\hline & & Pertemuan 1 & Pertemuan 2 & Pertemuan 1 & Pertemuan 2 \\
\hline 1. & M K U & 80 & 80 & 80 & 90 \\
\hline 2. & A A M & 70 & 70 & 70 & 90 \\
\hline 3. & A F & 80 & 80 & 80 & 90 \\
\hline 4. & A I & 70 & 70 & 80 & 80 \\
\hline 5. & $\mathrm{ACP}$ & 50 & 60 & 60 & 80 \\
\hline 6. & $\mathrm{~B} \mathrm{M}$ & 70 & 70 & 70 & 80 \\
\hline 7. & D A H & 60 & 60 & 70 & 90 \\
\hline 8. & D A R & 80 & 80 & 80 & 80 \\
\hline 9. & E P P & 80 & 80 & 90 & 90 \\
\hline 10. & J R M & 70 & 70 & 75 & 90 \\
\hline 11. & M. F.R & 70 & 70 & 75 & 90 \\
\hline 12. & M S & 60 & 60 & 60 & 90 \\
\hline 13. & M. F R & 70 & 70 & 80 & 80 \\
\hline 14. & M R R P & 70 & 70 & 80 & 80 \\
\hline 15. & R R & 70 & 70 & 75 & 80 \\
\hline 16. & M R & 60 & 60 & 70 & 90 \\
\hline & Jumlah & 1.110 & 1.120 & 1.195 & 1.370 \\
\hline & Rata-rata & 69,38 & 70 & 74,68 & 85,63 \\
\hline & $\begin{array}{c}\text { Persentase } \\
\text { Ketuntasan KKM }\end{array}$ & $69 \%$ & $70 \%$ & $74 \%$ & $85 \%$ \\
\hline
\end{tabular}




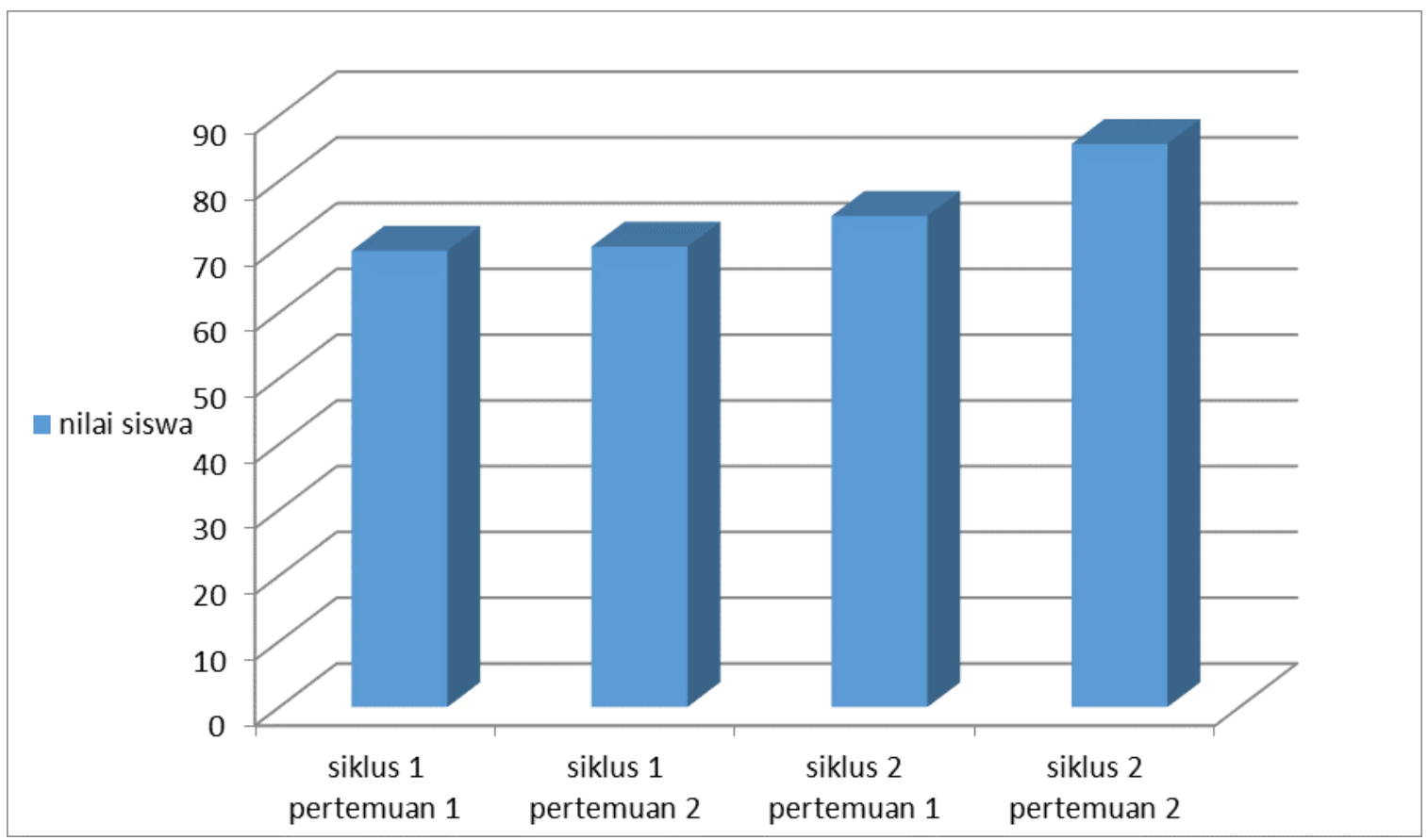

Gambar 1. Peningkatan Hasil Belajar Siswa

Dari gambar 1 dapat diamati bahwa, hasil belajar siswa mengalami peningkatan pada tiap pertemuannya. Pada pertemuan pertama materi menyusun karangan, siswa masih agak kesulitan, terutama terhadap cara mencari ide pokok setiap gambar, mengembangkan ide pokok dari setiap gambar, hingga disusun menjadi sebuah karangan yang tepat. Hal tersebut diketahui dari ratarata hasil belajar siswa hanya memeroleh nilai 69. Pada pertemuan ke-2, penggunaan media pembelajaran mulai membuahkan hasil, pada materi tahapan siklus air dan contoh masingmasing macamnya, ratarata hasil belajar siswa mengalami peingkatan sebesar 1 poin, menjadi 70. Pada pertemuan ke3, materi faktor yang memengaruhi dan fungsi masing-masing macamnya, kembali mengalami peningkatan sebesar 4 poin, menjadi 74 . Terakhir pada pertemuan ke-4, materi menyusun karangan berdasarkan gambar seri yang disediakan guru mendapatkan ratarata hasil belajar 85, dengan persentase ketuntasan KKM 85\%.

Keefektifan media gambar seri menjadi faktor penyebab peningkatan hasil belajar ini. Melalui media gambar seri, siswa menjadi lebih tertarik belajar, dan dapat mengaitkan gambar seri dengan baik. Seperti pendapat Azhar Arsyad dalam buku yang berjudul "Media Pembelajaran " media adalah bagian yang tidak terpisahkan dari proses belajar mengajar demi tercapainya tujuan pendidikan pada umumnya dan tujuan pembelajaran disekolah pada khususnya (Sadiman, 2006). Sedangkan menurut Djamarah dan Aswan Zain (1996) dalam bukunya "Strategi Belajar Mengajar " media adalah alat Bantu apa saja yang dapat dijadikan suatu penyalur pesan guna mencapai tujuan pengajaran. Menurut Poerwo Darminto (1987) dalam buku " Kamus Besar Bahasa Indonesia “ media gambar adalah tiruan barang-barang 
PTK, Vol.2 No.2 2022

ISSN: 2747-1977 (Print) / 2747-1969 (Online)

DOI: https://doi.org/10.53624/ptk.v2i2.56

(orang, binatang, tumbuhan dan sebagainya). Sedangkan menurut Cece Wijaya (1991) dalam buku “ Kemampuan Dasar Guru Dalam Proses Belajar Mengajar " menyatakan pengertian media gambar adalah media visual yang dapat diamati oleh orang yang memandangnya sebagai wujud perpindahan dari keadaan yang sebenarnya, baik mengenai pemandangan benda atau barang maupun suasana lingkungan.

\section{KESIMPULAN}

Berdasarkan hasil dan pembahasan di atas, dapat disimpulkan bahwa, media gambar seri untuk menyusun karangan dapat meningkatkan hasil belajar siswa pada materi menyusun karangan. Melalui media gambar seri ini, siswa dapat lebih terstimulus untuk mengeksplorasi pada kepingan-kepingan gambar yang didalamnya termuat materi pembelajaran. Melalui media gambar seri, peserta didik dapat lebih aktif dalam mengikuti pembelajaran, media gambar seri memiliki warna dan potongan gambar yang bervariasi sehingga lebih menarik serta akan memudahkan pengajar dalam menyampaikan isi materi.

\section{DAFTAR PUSTAKA}

Darminto, Poerwo, WJS. 1987. Kamus Besar Bahasa Indonesia. Jakarta: Balai Pustaka

Djamarah, Syaiful Bahri dan Aswan Zain.1996. Strategi Belajar Mengajar. Jakarta : Rineka Cipta

Hamalik, Oemar. 1986. Media Pendidikan. Bandung : Alumni.

Purwanto, Edi. 2010. "Peningkatan Keterampilan Menulis Deskripsi Melalui Pendekatan Kontekstual Pada Siswa SD Negeri 2 Sambeng Boyolali Tahun 2010."

Sadiman, Arief S, dkk. 2006. Media Pendidikan. Jakarta: Raja Grafindo Persada

Safaria, Triantoro, Ahmad Muhammad Diponegoro, and Khoiruddin Bashori. 2017. "The Efficacy of Gratitude and Forgiveness Training to Increase Happiness." The Social Sciences 12(11):1948-51.

Wijaya, Cece. 1991. Kemampuan Dasr Guru Dalam Proses Belajar Mengajar. Jakarta: Remaja Rasdakarya. 